\title{
Bringing Together Psychology and Peace: A Critique towards the Emancipatory Potential of Peace Psychology
}

\author{
Reunir la psicología y la paz: una crítica hacia el potencial \\ emancipatorio de la psicología de la paz
}

Artículo de reflexión

Fecha de recepción: 30 de junio de 2019 Fecha de aceptación: 31 de octubre de 2019

* Center for Social Studies, Faculty of Economy, University of Coimbra and Faculty of Education and Psychology, Regional Center of Porto, Catholic University of Portugal.

** Faculty of Education and Psychology, Regional Center of Porto, Catholic University of Portugal.

*** Faculty of Education and Psychology, Regional Center of Porto, Catholic University of Portugal. 


\title{
Para citar este artículo
}

Soares, M., Sá Caetano, A., \& Barbosa, M. (2019). Bringing Together Psychology and Peace: A Critique towards the Emancipatory Potential of Peace Psychology. Campos en Ciencias Sociales, 8(1), 33-60. DoI: https://doi.org/10.15332/25006681/5715

\begin{abstract}
Historically, psychology has been deeply associated with the defense and active normalization of conflicts, war, and established social orders. For instance, it is well-known that one of the most important grounds for the legitimacy of psychology as a scientific discipline depended on psychologists' work done during the First and Second World Wars. At those times, and perhaps in a culturally biased way, psychological tests for military selection and practical models to treat war-related problems were widely employed. Psychology gained a practical terrain for professionalization for both clinical and social psychologists within such context. However, psychology has also been used on behalf of emancipation, and not always in the field of conflicts, war, and oppression. One of the most interesting critical movements which has tried to move psychology into an emancipatory realm has been Peace Psychology. In general, this discipline has been open to framing, discussing, and participating actively in interventions developed in the name of peace and human rights. In accordance, in this paper, we seek to capture a) the historical development of peace psychology; b) the establishment of peace psychology as a field of psychology and of peace studies; and c) some reflections upon the omnipresent challenges and possible co-options that may shape the emblematic critical engagement of this discipline.
\end{abstract}

Keywords: peace; peace studies; psychology; human rights; history. 


\section{Resumen}

Históricamente, la psicología ha tenido vínculos profundos con la defensa y la normalización activa de conflictos, guerras y órdenes sociales establecidos. Por ejemplo, es bien sabido que uno de los fundamentos más importantes de la legitimización de la psicología como disciplina científica dependió del trabajo de los psicólogos durante la Primera y la Segunda Guerra Mundial. En la actualidad, ha sido bastante extendido el uso de pruebas psicológicas (posiblemente con un sesgo cultural) para la selección de personal militar y de modelos para tratar problemas relativos a la guerra. Dentro de tal contexto, la psicología ha ganado terreno en la profesionalización de psicólogos tanto clínicos como sociales. Con todo, la psicología también se ha usado a favor de la emancipación, y no siempre de los conflictos, la guerra y la opresión. Uno de los movimientos críticos más interesantes que ha tratado de llevar la psicología a un ámbito emancipatorio es la psicología de la paz. En general, esta disciplina ha mostrado gran entusiasmo por enmarcar, discutir y ser práctica y vigorosa en intervenciones desarrolladas en nombre de la paz y los derechos humanos. Por lo tanto, en este artículo buscamos aprehender: a) el desarrollo histórico de la psicología de la paz; b) el establecimiento de la psicología de la paz como un campo de la psicología y los estudios sobre la paz; y c) reflexiones sobre los retos ubicuos y las posibles opciones que podrían darle forma a la emblemática labor crítica de la disciplina.

Keywords: paz, estudios sobre la paz, psicología, derechos humanos, historia.

\section{INTRODUCCIÓN}

In different times and spaces, psychology has been found on the wrong side of history. Several examples can show how psychology has been a strong ally of conflicts, war, and oppression in its various forms. For example, the scientific racism born in the mid-nineteenth-century had the strong support of psychologists of that time, as the work of Francis Galton illustrates; and, similarly, the search for race differences has been a major concern in several studies of personality, social, and cultural 
psychology throughout the past century (cf. Richards, 2010). Also, psychology has been associated with male-centered and patriarchal positions which tried to underline women's inferior inner functioning, such as different personalities or other essentialist features (for a more systematized critique, see Kurtis \& Glenn, 2015). Another common example relates to the fact that psychology gained professional legitimacy during and in the aftermath of the First and Second World Wars, when clinical psychologists worked towards the construction of military psychometrics and models of intervention focused on war-related problems (Barbosa, Matos, \& Machado, 2011; Christie, Wagner \& Winter, 2001; Wessels, 1996).

On the other hand, psychology has also been used on behalf of emancipation, and not always in the reproduction of conflicts, war and oppression. One of the most interesting critical movements, which has tried to move psychology into an emancipatory realm, has been Peace Psychology. In general, this discipline has been open to framing, discussing, and participating actively in interventions developed in the name of peace and human rights. (cf. Christie, 2006; Christie et al., 2008; Christie, Wagner \& Winter, 2001; Christie, Tint, Wagner, \& Winter, 2008). However, peace and human rights imply many critical engagements. They are floating signifiers (Douzinas, 2007), which means that they can mean different things in different times and spaces, and the same goes for the case of peace. Peace and human rights belong to an interstice between domination and emancipation processes (Tapia, 2015). This also means that peace and human rights do not always favor the fight against wars and oppression. For instance, Jorge Rafael Videla, the well-known dictator of Argentina, used to say he was fighting for the human rights of the good citizens of Argentina. On the contrary, several claims and bottom-up struggles can be portrayed according to ideas of peace and human rights, like the struggles of indigenous populations for access to a river which is vital for their survival or the struggles of women's movements for legal reform (e.g., the condemnation of femicide) as a matter of human rights. Thinking about this kind of contradictions does not only pertain to the work of historians, lawyers, diplomats, social scientists, or experts in international relations. The work of psychologists, in general, and peace psychologists, in particular, are part of certain power relations that cannot be naturalized and overlooked. 
In this text, we take peace psychology as our scope of analysis. Our goal is to present a brief history of peace psychology, which has been founded both within psychology itself and within the peace studies interdisciplinary field as well. Then, in the last section of this paper, we reflect upon five critical points regarding the emancipatory potential of peace psychology. This means that peace psychology, as well as peace studies in general, have been constructed around the promise of building approaches and models of intervention that can foster negative and positive logics of peace, while fighting oppression, violence, and human rights violations in their various forms. In this sense, our effort is to interrogate some contemporary challenges associated with that mission. Indeed, we reflect upon the power relations that may permeate the mobilization of peace (both in its negative and positive forms) and human rights discourses and also the importance of a systematic anti-capitalistic, anti-colonial, and anti-patriarchal approach within peace psychology, which requires a relentless dialogue with social movements and struggles.

It is worth noting that these and other reflections contained in this paper do not intend to portray peace psychology as a monolithic field which has inherently lost its potential for violence prevention, peace promotion, and the pursuit of radical social transformation. Surely there is a vast and antagonistic range of political and social perspectives mobilized by peace psychologists. Still, we try to analyze and systematize the omnipresent risks, the power relations at stake, and the possible counterproductive effects of peace psychology approaches and models of intervention, while taking it in an abstract broader sense. This is a critical and self-reflective exercise which does not aim to homogenize and to discredit peace psychology, but rather to strengthen it and to advance a general understanding of it.

\section{A Brief History of Peace Psychology}

Peace psychology was recognized as a specialized area of psychology during the 1980s, after a long process of evolution mainly rooted in the second-half of the twentieth century. In the beginning, it represented a small group of psychologists concerned with typical objects of study within psychology, such as social conflict, well-being, 
war, and violence (Christie, Wagner \& Winter, 2001), but whose conceptual and practical frameworks were differentiated and cutting-edge in comparison to the mainstream psychology of that time (Sapio \& Zamperini, 2007). To some extent, this distinctive character is documented because peace psychology has inserted psychological knowledge into a developing and soaring 'international nomenclature' (cf. Blumberg, 2006). On the other hand, peace psychologists have also developed an incisive critique of traditional psychology (e.g., the lack of engagement with grassroots movements, the search for objectivity and scientific neutrality) (Barbosa, Matos, \& Machado, 2011; Sapio \& Zamperini, 2007).

Historically, the Cold War defined the development of peace psychology once the need to thwart nuclear war was recognized. Similarly, it has subsidized a range of conflicts and violent scenarios thitherto less visible and detached from the typical, direct inter-state violence (e.g., liberation conflicts, civil wars, local conflicts supported by the United States and the Soviet Union) (Christie, 2006; Christie et al., 2008; Christie, Wagner \& Winter, 2001; Sapio \& Zamperini, 2007). Indeed, by that time, the threat of a nuclear war between the United States (Us) and the Soviet Union had generated a counter-reaction among psychologists. Because they were interested in debating a possible nuclear war and the action of the states involved, these pioneers had begun to self-proclaim themselves 'peace psychologists' (Christie, 2006; Wessells, 1996). Earlier, in their considerations, peace psychologists had advocated a multidisciplinary approach to deal with social and political problems at different levels (e.g., micro-levels, such as families and communities; macro levels, such as States or international spheres) (Wessells, Mckay \& Roe, 2010). During the Cold War, peace psychologists - mainly speaking from the us - published several works on the political and psychological foundations of nuclear war legitimacy, the creation of the otherness of the enemy, and us-Soviet Union relations, with regular publications in the Journal of Social Issues and in The Journal of Conflict Resolution (cf. Christie, 2006; Wessells, 1996). Within this framework, other pioneering contributions for the subsequent establishment of peace psychology were developed: Quincy Wright, William Evan, and Morton Deutsch (1962), Preventing World War III: Some Proposals; Herbert Kelman's (1965), International Behavior: A SocialPsychological Analysis; Ralph White's (1986) Psychology and the Prevention of Nuclear War; and Richard Wagner's (1986), Psychology and the Threat of Nuclear War. 
In opposition to the typical path established by mainstream psychology as an academic and applied science, the first 'peace psychologists' dissociated themselves from governmental, economic, and psychosocial practices based on 'realpolitik' ideologies, which were legitimizing violence, controlling public opinion, and profiting from armed conflicts and emotional problems (Christie, Wagner \& Winter, 2001; Sapio \& Zamperini, 2007). Therefore, peace psychologists developed public educational programs regarding nuclear power and its prevention, addressing issues like the social construction of the enemy, the non-violent resolution of conflicts, and the importance of peace education (Wessells, 1996). This activist stance. together with the Cold War context in which the American state was envisioning peace as a threat to its internal security, contributed to a long and difficult recognition of peace psychology as a division of the American Psychological Association (APA), only achieved after the end of the conflict in 1991 (Wessells, 1996).

In the post-Cold War context, the existing bipolarity of power between the United States and the Soviet Union was dissipated and new problems spread throughout the world (e.g., increased economic and social disparities, displaced populations) which, in turn, have enlarged peace psychology's spectrum of research and practice (Christie, 2006; Christie et al., 2008; Christie, Wagner \& Winter, 2001). Hence, peace psychology has gradually moved away from a theoretical and practical activity concerned only with nuclear activism. It has become more nuanced by geopolitical, economic and historical conditions, and events, which gained particular visibility starting in the 1990s (e.g., ethnic violence, displaced populations, the Gulf War, the Bosnian War) and also has come to develop a more well-systematized outlining nomenclature (cf. Christie, 2006), even though it has always remained attached to the early notions of negative, positive, and cultural violence, developed by Johan Galtung (1969) within the peace studies framework.

At the theoretical level, the Society for the Study of Peace, Conflict and Violence (2006 cited in Christie et al., 2008: 540) has come to define peace psychology's goals as follows: "[...] increase and apply psychological knowledge in the pursuit of peace [...] [including] both the absence of destructive conflict and the creation of positive social conditions which minimize destructiveness and promote human well-being." The construction of peace cultures, as well as the understanding, management, and 
prevention of conflicts and violence ${ }^{1}$, are the main goals of this discipline. It engages in different levels of analysis (e.g., family, school-based, international conflicts) and in transdisciplinary issues (e.g., gender discrimination, urban violence, ecological health) (Wessells, 1996).

Peace psychology is attentive to traditional themes of psychological science but trying to frame them in a different manner. In this sense, subjective suffering is not situated mainly in the individual, nor is it seen as a result of a lack of coping skills. Rather, human suffering is a genuine by-product of dysfunctional arrangements and, as such, it is an epiphenomenon (Sapio \& Zamperini, 2007). As a result, peace psychology criticizes the traditional psychological approaches for their lack of social relevance, advocating that psychology should move from 'objects of study' to 'real problems' in order to think and speak up about the structural power differences which are shaping the construction of the subject (Sapio \& Zamperini, 2007).

Following a peace studies framework, peace psychology adopted negative and positive logics of reasoning in order to analyze these problems. Described and analyzed first by Johan Galtung (1969), negative peace and positive peace aim to translate respectively the absence of direct and structural violence. Direct violence refers to the visible and manifested forms of violence between groups and states (Cohrs \& Boehnke, 2008; Galtung, 1969). Direct violence involves offences producing concrete damages which can affect the physical and psychological well-being of the subjects or groups, or property damages. In sum, it is a direct, episodic and periodic form of violence (Christie, 2006; Christie, Wagner \& Winter, 2001; Galtung, 1969; Wagner, 2001). For instance, armed conflicts can be seen as forms of direct violence and as barriers to achieving negative peace. In turn, negative peace can be accomplished by settling

1 It goes beyond the scope of this paper to discuss the insights about conflict management and resolution which are central to peace psychology foundations. One of the most influential models was developed by Johan Galtung (2007) - TRANSCEND approach - which is focused on the reconstruction of the untransformed (relational) conflict through creative and non-violent means. Other inputs can be gathered under two categories, namely interest-based and needs-based approaches (cf. Christie et al., 2008). The former is directed to negotiators who try to propose agreements satisfying the interests of the conflict's parties. The latter-an interactive problem-solving approach-is oriented to academics who are facilitators of the resolution of violent conflicts. The facilitators are third-parties who bring nonbinding and different perspectives to the conflict serving as an external pressure. 
the conditions to stop conflicts and war through peacemaking and peacekeeping (Christie, Wagner \& Winter, 2001).

On the other hand, structural violence refers to the systematic and insidious oppression which prevents subjects and groups from achieving an optimal level of development (Christie, 2006; Cohrs \& Boehnke, 2008; Galtung, 1969). Structural violence is more manifest in some social segments due to classist, colonialist, and patriarchal societies, but it is seen as a commonplace, chronic, impersonal and blurred. It is implemented by means of socioeconomic arrangements depriving individuals from the resources required to satisfy their needs (Christie, 1997; Galtung, 1969). Peace cannot be understood just as the mere absence of direct forms of violence. For Galtung (1969), positive peace could be compared to the achievement of social justice. Psychological and ideological processes sustaining social injustice or social inequality, as the belief in a just-world (Hafer \& Choma, 2009) or systems inevitability (Kay, Jimenez, \& Jost , 2002), can pose important cognitive obstacles to positive peace. Education for peace and human rights or liberation psychology can be examples of triggers for positive peace.

The distinction between direct and structural violence, and between negative and positive peace, do not aim to generate a binary and non-integrative understanding of these two as independent phenomena. On the contrary, direct and structural forms of violence are interconnected problems: socially-dominated, politically excluded or economically exploited groups are more likely to suffer from direct forms of violence (Christie, Wagner \& Winter, 2001). This model is a systematic one, in which direct and structural mechanisms are fused within an interactional, dynamic, and circular system of violence (Christie, 2006).

A third type of violence - cultural violence - also deserves to be clarified for purposes of this article. Cultural violence refers to those symbolic and soft aspects, like language, science, and ideology, used to justify and to legitimize direct and structural violence (Galtung, 1969; Galtung \& Fischer, 2013). Cultural violence is a kind of semiotics of violence whereas cultural peace would represent the cooperation and mutual understanding of different cosmologies (Galtung, 2005). Cultural violence 
here may reflect the hegemonic and pervasive power of the core globalized systems of knowledge and socioeconomic organization (i.e., capitalism, colonialism and patriarchy) constructed to dissimulate, disregard, and legitimize the imposition of these knowledges over the others (cf. Santos, 2011).

But what kind of innovations do peace psychologists put forward in comparison to more so-called traditional branches of psychology? Do they look for synergies with other disciplines within psychology? How do they subsidize the interdisciplinary field of peace studies? The next two sections aim to answer these questions while understanding peace psychology as a field of psychology and of peace studies.

\section{Peace Psychology as a Field of Psychology}

Generally speaking, the critiques of peace psychologists regarding mainstream psychology will be discussed in accordance with three axes of analysis: a) the psychological emphasis on war and conflicts (Blumberg, 2006); b) the formulation of local knowledge with ambitions of universal validity (Sapio \& Zamperini, 2007); c) the neutrality and objectivity traps (Sapio \& Zamperini, 2007). To begin with, peace psychology criticizes traditional psychology for its focus on direct violence, that is, on wars and conflicts, usually forgetting the importance of discussing nonviolence, structural violence, positive peace, and the construction of cultures of peace:

Developmental, psychodynamic and mental-health research covers all of the categories but is concentrated on delineations of direct violence. Included are studies of child soldiers (and prevention and rehabilitation), of the impact of war on children, and of children's attitudes towards hostilities - also, as concerns adults, the ubiquity of conflict, how it can be ameliorated, and studies of people in (or from) war-torn and conflict ridden areas. (Blumberg, 2006, p. 10)

But peace psychologists extend this critique by remembering that psychology was founded and has gained legitimacy in the service of war, conflict, and the status quo. 
As described above, psychology gained recognition as a scientific discipline during the first and second world wars of the 20th century (Barbosa, Matos \& Machado, 2011; Sapio \& Zamperini, 2007). As a response to this, peace psychology has then emphasized the need to extend the application of psychology's gaze to nonviolence and peace promotion (Leidner, Tropp, \& Lickel, 2013).

In the second place, mainstream psychology can be criticized for its claim to the universal validity of local knowledge built within liberal countries which concentrate a lot of political and economic power (cf. Hogan \& Vaccaro, 2006): the global north is the conspicuous place where psychological knowledge production is developed. Relying on the acronym weIRD (i.e., Western, Educated, Industrialized, Rich and Democratic societies), Henrich and colleagues (2010) have criticized the experimental branches of psychology - like cognitive science, behavioral sciences by discussing how the supposedly leading scientific and empirical data reflects the experiences and the contexts of a dominant WEIRD minority. The problem arises when we acknowledge that these findings are routinely assuming, at least implicitly, that it is possible to generalize, to make inferences about the human mind or human behavior, without questioning the epistemic validity of the whole process. It does not question the colonial-based academic relations sustaining psychological knowledge production in academic realms. The demand of scientificity leads psychology to a historical association with a quantitative orientation since validity and reliability depend on quantitative techniques applied to measurable human beings (Cosgrove, Wheeler \& Kosterina, 2015).

Thirdly, another important critique held by peace psychologists, is concentrated on how mainstream psychology lacks social relevance, coupled with the aim to scientific neutrality both in how it applies previous individual-centered theoretical frameworks to peace study, as well as how psychology, in general terms, is guided by individualistic approaches (Sapio \& Zamperini, 2007). Historically, the legitimation of psychological science has led to the development of hermeneutical frameworks whose relevance for social transformation is quite debatable. Few disciplines within Psychology have been politicized in such a way that they have the potential to disrupt the hegemonic versions of knowledge production, with exceptions such as liberation psychology in Latin America (Martin-Baró, 1994) or European critical psychology 
(Parker, 2015). Moreover, peace psychology shares theoretical assumptions and constructs with political psychology (e.g., analysis of cognitive processes in regard to peace and conflict decision-making), social psychology (e.g., interest in the origins and maintenance of conflicts), and positive psychology (e.g., the creation of positive social conditions) (Christie, 2006; Christie et al., 2008; Sanson \& O’Connor, 2012).

Surely, all of the aforementioned critiques come not only from peace psychology, but also from other related fields of psychology, such as cultural psychology or liberation psychology. In truth, what gave these critiques a particular backdrop within peace psychology was the promise of creating a new radical, alternative and promoting an international nomenclature able to reply to the previous criticisms (e.g., lack of social relevance, the hegemony of North knowledge production). Put slightly differently, for peace psychologists, the very possibility of creating approaches, methods and models of intervention that could serve social transformation, oppressed minorities' interests, and prompt a horizontal dialogue with other forms of knowledge (scientific or not) was not only possible but would be achieved by a paradigmatic shift (cf. Webel $\&$ Galtung, 2007). The aim was always the internationalization of peace psychology, although the assurance was that it could be done in non-WEIRD manners. But does peace psychology have the ability to keep its radical stance unscathed and wellestablished? In general terms, what are the current challenges which could jeopardize peace psychology as an academic critical movement? Has peace psychology been completely successful in addressing the previous critiques in its own practices and models of intervention? To answer these questions, it is important to have a broader picture of peace psychology within peace studies in general.

\section{Peace Psychology as a Field of Peace Studies}

The history described so far has shown signs of the deep embeddedness and legitimation that peace psychology had within the development of peace studies terminologies, as reflected in the adoption of negative and positive peace concepts. Peace psychology is an ineluctable part of the broad discursive atmosphere and multidisciplinary conceptual framework merging several perspectives with international relations (Wessells, 1996). 
Taking the broader field of peace studies, it should be noted that, as a critical movement, it has represented a post-positivistic rupture with the international affairs field exclusively dedicated to understanding conflicts (Pureza, 2011). Peace studies have represented a shift from war to peace, from violence to non-violence, from conflict profiting to conflict resolution. However, since the 1990s onwards, peace studies have started to be usually co opted by the dominant international system through funding agencies and platforms of global governance (Pureza \& Cravo, 2005; Pureza, 2011).

Peace studies have begun to be again established based on a "deep culture of militarism", that is, on a sharply negative logic concerned with war, violence, and, mainly, armed conflict (Attack, 2009, p. 44). Moreover, peace studies have since then been moving away from social movements and other forms of social struggles, acting usually in peripheral countries seen as borderlands which need humanitarianism and civilization (i.e., in the so-called "new wars" and in the basis of the non-governability of "failed-states", usually attributed to inner causes), and therefore losing their ground as an academic critical movement (Pureza, 2011). As José Manuel Pureza (2011: 15) states, a movement that aspired to a radically different manner of portraying violence and peace ended up developing repeated interventions which separate the center from the periphery, as "state building, nation building, capacity building, institutional building may be assumed to be mere technical devices, yet they have transformed the very sovereignty of the so-called failed-states" into projects of coresponsibility shared by the state per se and international public-private partnerships (i.e., states, intergovernmental agencies and non-governmental organizations). The author believes that the paradigm shift may have just modified languages and not material conditions: "Partnerships', 'country-owned strategies', 'increasing local empowerment' are now the vocabularies [...] that reveal the practices of global governance which are currently being conducted by the system center, which both rhetorically and politically repudiate the density of a true empire", although still acting in (self-denied) imperialistic forms.

A scientific normalization appears to be taking place, whose radical character remains only visible in conceptual and superficial levels (Hagmann, 2014; Pureza \& Cravo, 
2005; Pureza, 2011). A tame and subordinated conceptualization of peace seems to have been more and more vulgarized:

As international aid agencies compressed positive peace into the logic of project cycle management, peace has become increasingly instrumentalist and prescriptive. Peace is no longer political, but it is plannable and measurable, a composite of indicators that can be evaluated once the project draws to its close. This is a shallow peace, not real peace. Not the kind of peace that addresses inequality, domination or power imbalances. It is 'donor peace', modelled on the same vague yet orthodox idea of liberal peace, which is held to be universal and exportable like spare car parts. Donor peace is a sophisticated type of pacification that seeks to change target groups' behaviour not with the threat of military might but with the persuasion of per diems. When most pronounced, donor peace shares many traits with neoliberalism as it concomitantly commodifies, bureaucratizes and individualizes peace. In the most extreme, violent conflict in the global South is no longer viewed in terms of struggles for rights, liberation or self-determination, but as criminal, senseless and/or threatening Western security interests. (Hagmann, 2014, p. 8)

In our opinion, peace psychology has to a certain degree accompanied this process, taking the same paths of peace studies in general. To some extent, some of the critical intents of peace psychology in regard to mainstream psychology may not be fully realized in the face of processes of accommodation and of disputes of powers that are presented within peace and human rights vocabularies (cf. Douzinas, 2007; Tapia, 2015). In addition, peace psychology is still profoundly directed toward conquering a space of legitimacy. The contestation of the broader frameworks could be assumed as dangerous to its fragile course. Once the institutionalization of the sub-discipline is aspired to in order to gain relevance, the support and acceptance by the mainstream institutions are often not questioned. This means that the 'urgent professionalization' is paradoxically needed to legitimize the "progressive or radical models" of peace psychology's models of intervention. To serve different ideals and horizons, the reinvention and recreation of psychologies need to constantly be advanced. In other words, peace psychology is still being challenged by the difficult mission of "finding a place in and against psychology" (Parker, 2015, p. 7), while, at 
the same time, it needs to go beyond psychology itself (cf. Hook, 2005). The following part of this article discusses some critical reflections that need to be omnipresent in peace psychology if the emancipation of those who are more victimized by direct, structural, and cultural forms of violence is to be driving force of this field.

\section{Going BACK to Go Forward: ReFlecting UPON THE Emancipatory Potential of Peace Psychology}

In the conclusion of their book, Galtung and Webel (2007) carry out an analysis of the past and future of peace studies. Of paramount importance, according to the authors, is the preservation of an independent, critical, and emancipatory movement. It is important to put the present and future in dialogue in order to rescue the original endeavors of this field (Pureza, 2011). We need to go back to the critiques applied to the mainstream perspectives, asking the same hard hitting questions to our own so-called current, "critical", "progressive", or "radical" perspectives. The extent to which they might become co-opted or counterproductive is proportional to our ability to question our own perspectives and limits of action. Hereinafter, we put forward five important remarks on this matter.

Our first remark takes into account the fact that peace psychology often relies on human rights discourses and on peace as an end in itself, but rarely questions the hegemonic meanings ascribed to both. It proclaims the need for peace education and increased human rights awareness, but without questioning the hegemonic meanings and processes related to these discourses. For instance, human rights rhetoric can be cynical and compatible with neocolonial and neoliberal conceptions of 'global dominance'. A solipsist discourse reproducing a tradition of cultural violence which peace psychology is supposed to be fighting against. Several authors have stressed (e.g., Bertherton \& Balvin, 2012; Campbell, 2006; Douzinas, 2007) how human rights are a Western-based conception translating an individualistic, universalized, normative, and performative approach to human dignity.

Human rights hegemonic discourses are often located within global and international realms due to intentions of applying a specific view of the human being worldwide. 
In opposition to "a politics of citizenship of home, the other [human rights implied] a politics of suffering abroad" (Moyne, 2010, p. 12). But human rights' appealing universality obscures its exclusionary character. The modern and individualistic conception of human rights is close to a Cartesian conception of being, connecting a coloniality of knowledge (i.e., the need for rationality) with a coloniality of being (i.e., the need for being human) (Maldonado-Torres, 2007). The persistence of a colonial discourse is notorious when we understand that the conception of the human being is an abyssal one. Being recognized as human implies the allocation of humanity and, within human rights project, there are lives that from the start do not count as human, as they can be understood as ungrievable lives (Butler, 2009).

It is within this framework that several international and humanitarian missions are legitimized. Neoliberal ideology is evidently entrenched in these discourses. Human rights are omnipresent tools for exerting moral authority. At the same time, they have become pervasive in their recent times of existence, and a lot of endemic problems of the mainstream discourse are usually ignored (Campbell, 2006). Most of the time, human rights are not instrumentalized on behalf of the individuals or collectivities whose lives and rights are being violated (Chandler, 2004). This is true with respect to the consolidation of both state-building and peacebuilding in the so-called failed-states. International jargon based on the idea of global policies has often been accepted and legitimized at the cost of sovereignty and bottom-up consent (Richmond, 2014). Different countries and regions in the world, usually devastated by war, other armed conflicts, and political instability are instructed in and subjected to the norms of liberal policy, that means to "[...] aggressive democratization schemes, hurried democratic elections, and intensive state-building projects" pursuing the establishment of market and liberal-democratic economies (Thiessen, 2011; p. 116). Psychologists are usually trained to work within the same NGOs which are providing the technical and often ambiguous interventions built within these frameworks (cf. Hagmann, 2014).

In this scenario, our first central reflection is coming to the fore. Peace psychology approaches and models of intervention may grant an acceptable academic face to these international actions of peacebuilding without inquiring into the power relations at stake and their colonial trace, as they may deny self-determination 
to others in the processes of building their own sovereignty (cf. Pureza, 2011). Also, these interventions might not take into account the unwillingness of other peoples to be recipients of such interventions, or accept those other local models of intervention preferred by local people (i.e., reconciliation models), because those kinds of interventions are not supported by international agencies and so they do not generate opportunities for technical work and for application of psychological models of intervention.

So whose rights are peace psychologists fostering and promoting? More often than not human rights are constructed as an individual, universal, legalist, and normative discourse. Interventions led within this frame are not exempt from the endemic problems that the mainstream discourses on human rights and peace are carrying out. Even the strategic use of human rights or peace, in the name of collective rights or indigenous claims, cannot ignore the fragile premises and power disputes that wellknown human rights and peace discourses encompass. This point raises the question of how to build counter-hegemonic discourses once hegemonic discourses do not recognize the need to reformulate the canon in the light of local specificities, while resistance and counter-movements — which are fighting against power relations and oppression - tend to formulate their claims in an inharmonious language of human dignity (Santos, 2013).

Following these ideas, we stress, in the second place, the need for a critical engagement with how intercultural narratives, advanced by peace psychology, are carried out when it comes to building cultures of peace. Frequently, peace psychology's discourses tend to foster the cultural inclusion of those who are marginalized and excluded due to direct and structural mechanisms. However, the manner in which the intercultural dialogue can be operative and how it can work on behalf of those who have suffered different violations is still a very controversial issue (cf. Sanson \& O'Connor, 2012; Bertherton \& Balvin, 2012). The recognition of interculturality is not the sole condition needed to bring about a transformative intercultural dialogue.

This analysis may highlight the need to ask about the impossibilities that may arise during the intercultural dialogue, rather than simply questioning what is possible 
during cultural encounters. Mutual learning and exchange are important grounds for development and growth and this recognition does not necessarily imply a pure relativism; rather, it can foster counter-hegemonic insights and emancipatory points of departure to address a multicultural conception of human rights (Santos, 2002; 2007). As peace psychologists, we need to acknowledge the impossibility to apprehend the incommensurable experiences and knowledge in the world(s) by means of what one may call learned ignorance ${ }^{2}$ (Santos, 2009). Hence, the challenge here does not lie in the complete refusal of psychological knowledge as a useful episteme, but in how it can be helpful to transform realities that (Western) peace psychologists are never going to be able to apprehend due to a certain lack of epistemic privilege. For peace theorists, as Thiessen (2011) explains, for instance, in emancipatory peacebuilding, a self-reflective stance held by international actors can support the recovery of a critical dialogue which is able to respect bottom-up decisions, sovereignty, and sociocultural backgrounds.

Peace psychologists must then be willing to conduct fluid and complex analyses of their interventions and actions. In this sense, other questions can emerge. Are other cosmologies going to be fully realised within an Western integrative rhetoric? Is it helpful or redundant? To whom? Whose peace and conflicts are we engaging in? Is a peace psychology intervention always required, or can inaction be the best way of pledging self-determination? To face uncertainty, one of our best 'imperfect' scripts

2 Santos (2009) debates the concept of learned ignorance by taking into account the usual discrepancy between what the author calls strong questions (i.e., problems of individual and collective life dictating the horizon of possibilities to embrace) and weak answers (i.e., refusal to abandon and to question the limits of 'plausible' possibilities). According to the author,

[...] the discrepancy between the strength of the questions and the weakness of the answers seems to be common. It derives from the current variety of contact zones involving cultures, religions, economies, social and political systems, and different ways of life, as a result of what we ordinarily call globalization. (Santos, 2009, p. 109)

We are not going to engage in a deep analysis of this chasm, but Santos posits a crucial argument to this discussion, namely how modern science is too reductive and partial to respond to the different important problems of the current world. Learned ignorance is then about the limits of scientific knowledges and disciplines themselves. This means the recognition of a radical uncertainty, a commitment to questions which sciences and disciplines have not previously foreseen in their scope. 
is once more the conduction of historical and context-rooted analyses. As Hegarty points out:

Ouroptimistic impulses to intervene psychologically in contemporary situations to engender peace should be counterweighted by historical recognition of the diverse effects of what psychologists have already done in history, often with intentions as positive as our own. Colonization has been justified through psychological rhetoric about the limits and potential of "native minds" and "decolonization" by notions of distinct national mentalities and characters. (Hegarty, 2014, p. 337)

Peace psychology needs to be actively engaged in the analysis of the historical conditions guiding its intervention, perceiving how conflict and peace are narrated by different audiences and how they are experienced and remembered - that is, processes of collective memory. Understanding what can be "positive" in the conflict and "negative" in a misleading peace is central to this process (Hegarty, 2014).

Thirdly, even recognizing that structural violence is everywhere and that positive peace is a major utopia in both the global North and South, peace psychology ends up with a voluminous literature on how to promote 'peace and human rights abroad' in postconflict societies. Within peace studies, and particularly amongst peace psychologies, there is still no systematized discussion about an agenda for positive peace (Pureza, 2011). By approaching the tendencies in the quantitative and qualitative aspects of the leading publications on peace psychology, Blumberg (2006) has shown a concrete focus on conflict resolution and in peace psychological research interested in crisis-ridden locations. Once more, other important questions ought to be asked. Acknowledging the encompassing view of peace psychology and the several structural problems characterizing WEIRD worlds nowadays, what kind of legitimacy can peace psychology claim to have abroad if it fails to debate the problems concerning the WEIRD worlds which have created it? Is the point of departure of peace psychology an anti-capitalistic, anti-colonial, and anti-patriarchal grassroots approach to building positive peace? 
Some important notes on this question should be made. Firstly, peace studies and, consequently, peace psychology are connected to an international framework in which the countries representing the fiction of the 'international community' are not widely problematized in terms of structural violence. They are subjects of human rights and peace; others are objects of human rights (Baxi, 2006). This is the difference between those who represent the 'international community' and who are subjects of peace interventions and those who are the 'national community', the recipients of these peace interventions (Pureza, 2011). Of course, this tendency must be reverted, and the analysis of macro-power relations has to be urgently relocated within peace psychology as a major concern.

Secondly, and in accordance with the previous note, there is no possibility of including all Western experiences within the WEIRD acronym. From the point of view of Boaventura de Sousa-Santos (2009) a novel interculturality needs to find room to enlarge and criticize what has also been wasted and stolen inside the West while creating and imposing the nomothetic version of the Western. How much poverty, deprivation, inequality, and non-democratic experiences have been presented in the contemporary West? In other words, how much structural violence is also present within the boundaries of Western countries and may often fall out of the scope of peace studies and peace psychology? In both Western and non-Western countries, it is of paramount importance to begin searching for an agenda for positive peace that entails alternative projects that could engender and prefigure post-capitalistic, postcolonial, and post-patriarchal relations (cf. Kagan \& Burton, 2000).

Fourthly, a critical dialogue and interface with other critical psychologies (i.e., critical psychology, liberation, feminist, cross-cultural psychology) is needed. Is peace psychology interested in engaging with social movements and struggles on this matter (e.g., postcolonial, feminist, anti-globalization), or does it still prefer to be mainly attached to an international technical jargon aimed at legitimizing humanitarian and peacebuilding intervention in the world's periphery? In fact, several previous entanglements of critical movements and psychology have been achieved and should be taken into account. Critical psychology, for instance, is central to continuously reexam psychology as a whole and peace psychology in concrete (Sanson \& O'Connor, 2012). However, peace psychology has been marginally discussed in handbooks about 
critical psychology (cf. Parker, 2015). Mainstream versions of peace psychology have dimly analyzed power differences and the importance of organizing with subaltern movements. On this topic, the dialogue between 'critical psychologies' is a crucial step in order to accomplish a critical and emancipatory psychology from below also when it comes to violence and peace processes.

Finally, we are notjustpeace orpacifyingpsychologists; we are intellectuals and practitioners pursuing an alternative peace imaginary. This final point is about remembering that sustainable peace cannot be exclusively attained by mere professionalization. Peace psychology can be a springboard for psychologists; however, they may be uncomfortable to ask these questions because they are still searching for legitimacy within both psychology and peace studies. They are still conquering a 'place of legitimacy' as policy advocators, consultants and expert witnesses, looking for the recognition of psychological expertise within the institutional realms of human rights policies (Migacheva, 2015).

Peace psychologists are facing a double risk: to remain withdrawn within both psychology and the related interdisciplinary fields of human rights and peace. Too secluded and disruptive for general psychology (even if latter assimilated); too peripheral and secondary for peace studies. Epistemic disobedience might require setting aside this professional concern, moving beyond the merely interdisciplinary disputes that are weakening the contestation of knowledge's enunciation and enunciators (Mignolo, 2009). So, engagement in epistemic disobedience is a worthwhile and imperative challenge ahead. Peace requires the commitment to peace imaginaries that go beyond the sphere of the "possible discourses", within and outside the boundaries of academia, in an attempt to search for utopic imaginaries. An emancipatory psychology must go beyond a mere inward-looking at certain critical engagements questioning knowledge production, social problems, oppressive relations and power dynamics as a whole (Hook, 2005). 


\section{Conclusion}

By providing important critiques to mainstream psychology and being part of the broader interdisciplinary field of peace studies, peace psychology is surely an important ground to highlight discussions and interventions led in the name of peace and human rights. To our knowledge, peace psychology still faces many challenges due to the continuous accommodation of its terminologies, and also to particular practical challenges. In this paper, we emphasized the historical roots of peace psychology and its foundation as a field of psychology and as a field of an interdisciplinary endeavor named peace studies. Then we advanced some current relevant reflections in order to debate how a radical and innovative field such as peace psychology may reproduce several dynamics of power. It was our final goal to try to search for important questions to make us continuously recall the emancipatory potential of peace psychology. Contradictions, moral problems, and risk of counterproductive interventions will be always be present for peace psychologists. In our view, self-reflection, the questioning of peace and human rights power disputes, a more oriented focus towards positive peace, engagement with grassroots movements, and epistemic disobedience are some key-defining features of an emancipatory intervention developed by peace psychologists in general.

\section{REFERENCIAS}

Arfken, M. (2012). Scratching the Surface: Internationalization, Cultural Diversity and the Politics of Recognition. Social and Personality Psychology Compass, 6, 428-237. DoI: 10.1111/j.1751-9004.2012.00440.x

Barbosa, M., Matos, R., \& Machado, C. (2013). A Psicologia da Paz. Psicologia, XXVII(1), 47-61.

Baxi, U. (2006). Politics of reading human rights: Inclusion and Exclusion within the production of Human Rights. In S. Meckled-García \& B. Çah (Eds.), The Legalization of Human Rights: Multidisciplinary Perspectives on Human Rights (pp. 182-200). New York: Routledge. 
Bertherton, D. \& Balvin, N. (2012). Conclusion: Peace Psychology Concepts for the Future. In D. Bretherton \& N. Balvin (Eds.), Peace Psychology in Australia (pp. 341-351). Australia: Springer.

Blumberg, H. (2006). Trends in Peace Psychology. In H. Blumberg, P. Hare, \& A. Costin (Eds.), Peace Psychology: A Comprehensive Introduction (pp. 3-16). New York: Cambridge University Press.

Butler, J. (2009). Frames of War: When is a life grievable? London: Verso Books.

Campbell, T. (2006). Rights: A critical introduction. London: Routledge.

Chandler, D. (2004). The Responsibility to Protect? Imposing the 'Liberal Peace'. International Peacekeeping, 11(1), 59-81. DoI: 10.1080/1353331042000228454

Christie, D. (1997). Reducing Direct and Structural Violence: The Human Needs Theory. Journal of Peace Psychology, 3(4), 315-332. DoI: 10.1207/s15327949pac0304_1

Christie, D. (1999). Peace Studies: The Multidisciplinary Foundations of Peace Psychology. Journal of Peace Psychology, 5(1): 95-99. DoI: 10.1207/s15327949pac0501_12

Christie, D. (2006). What is Peace Psychology the Psychology of? Journal of Social Issues, 62(1), 1-17. DOI: $10.1111 /$ j.1540-4560.2006.00436.x

Christie, D., Tint, B., Wagner, R., \& Winter, D. (2008). Peace Psychology for a Peaceful World. American Psychologist, 63(6), 540-552. Dor: 10.1037/0003-066X.63.6.540

Christie, D., Wagner, R., \& Winter, D. (2001). Introduction to Peace Psychology. In D. Christie, R. Wagner \& D. Winter (Eds.), Peace, Conflict, and Violence: Peace Psychology for the 21st Century (pp. 1-14). New Jersey: Prentice-Hall.

Cohrs, J., and Boehnke, K. (2008). Social Psychology and Peace: An Introductory Overview. Social Psychology, 39(1), 4-11. DOI: 10.1027/1864-9335.39.1.4 
Cornish, F., Haaken, J., Moskovitz, L., \& Jackson, S. (2016). Rethinking Prefigurative Politics: Introduction to the Special Thematic Section. Journal of Social and Political Psychology, 4(1), 114-127. DOI: 10.5964/jspp.v4i1.640

Cosgrove, L., Wheeler, E., \& Kosterina, E. (2015). Quantitative Methods: Science Means and Ends. In I. Parker, Handbook of Critical Psychology (pp. 15-23). New York: Routledge.

Douzinas, C. (2007). Human Rights and Empire: The Political Philosophy of Cosmopolitanism. London: Routledge.

Galtung, J. (1969). Violence, Peace and Peace Research. Journal of Peace Research, 6, 167-191.

Galtung, J. (2005). Três formas de violência, três formas de paz. A paz, a Guerra e a formação social indo-europeia. Revista Crítica de Ciências Sociais, 71, 63-75.

Galtung, J. (2007). Peace by peaceful conflict transformation - the TRANSCEND approach. In C. Webel \& J. Galtung (Eds.), Handbook of Peace and Conflict Studies (pp. 14-32). London: Taylor and Francis, LTD.

Galtung, J., \& Fischer, D. (2013). Johan Galtung: Pioneer of Peace Research. New York: Springer.

Galtung, J., and Webel, C. (2007). Peace and Conflict Studies: Looking back, looking forward. In C. Webel \& J. Galtung (Eds.), Handbook of Peace and Conflict Studies (pp. 1-39). London: Taylor and Francis, LTD.

Hafer, C., \& Choma, B. (2009). Belief in a Just World, Perceived Fairness and Justification of the Status Quo. In J. Jost, A. Kay, \& H. Thorisdottir, Social and Psychological Bases of Ideology and System Justification (pp. 107-125). Oxford: Oxford University Press

Hagmann, T. (2014). Revisiting Peace and Conflict Studies. In L.Goetschel \& S. Pfluger (Eds.), Challenges of Peace Research (Working Paper no 7 / 2014) (pp. 7-15). Bern: Swiss Peace. 
Hogan, J. D. \& Vaccaro, T. P. (2006). Internationalizing the History of U.S. Developmental Psychology. In A. C. Brock (Eds). Internationalizing the History of Psychology (pp, 133151). New York: New York University Press.

Hegarty, P. (2014). The need for historical understanding in the Psychology of Peace and Conflict. Peace and Conflict: Journal of Peace Psychology, 20(3), 337-340. Dor: 10.1037/ pac0000042

Henrich, J., Heine, S., \& Norenzayan, A. (2010). The weirdest people in the world? Behavioral and Brain Sciences, 33, 61-135. Dor: 10.1017/S0140525X0999152X

Hook, D. (2005). A Critical Psychology of the Postcolonial. Theory \& Psychology, 15(4), 475503. DOI: $10.1177 / 0959354305054748$

Kagan, C. \& Burton, M. (2000). Prefigurative Action Research: an alternative basis for critical psychology? Annual Review of Critical Psychology, 2, 1-15.

Kay, A. C., Jimenez, M. C., \& Jost, J. (2002). Sour grapes, sweet lemons, and the anticipatory rationalization of the status quo. Personality and Social Psychology Bulletin, 28(9), 1300-1312.

Kelman, H. C. (Ed.). (1965). International behavior: A social psychological analysis. New York: Holt, Rinehart \& Winston.

Kurtiş, T. \& Adams, G. (2015). Decolonizing Liberation: Toward a Transnational Feminist Psychology. Journal of Social and Political Psychology, 3(1), 388-413. Dor: 10.5964/jspp. v3i1.326

Leidner, B., Tropp, L., \& Lickel, B. (2013). Bringing science to bear - on Peace, Not War: Elaborating on Psychology's Potential to Promote Peace. American Psychologist, 68(7), 514-526. DOI: $10.1037 / \mathrm{a} 0032846$

Martin-Baró, I. (1994). Writings for a Liberation Psychology. London: Harvard University Press. 
Maldono-Torres, N. (2007). On the Coloniality of Being: Contributions to the development of a concept. Cultural Studies, 21(2-3), 240-270. Dor: 10.1080/09502380601162548

Migacheva, K. (2015). Searching for Puzzle Pieces: How (Social) Psychology Can Help Inform Human Rights Policy. Peace and Conflict: Journal of Peace Psychology, 21(1), 142-149. DoI: $10.1037 /$ pac0000089

Mignolo, W. (2009). Epistemic Disobedience, Independent Thought and De-Colonial Freedom. Theory, Culture and Society, 26(7-8), 1-23. Dor: 10.1177/0263276409349275

Moyne, S. (2010). The Last Utopia: Human Rights in History. Cambridge: Harvard University Press.

Parker, I. (Ed.) (2015). Handbook of Critical Psychology. New York: Routledge.

Pureza, J.M. (2011). O Desafio Crítico dos Estudos para a Paz. Relaçôes Internacionais, 32, 5-22.

Pureza, J. M., \& Cravo, T. (2005). Margem crítica e legitimação nos estudos para a paz. Revista Critica de Ciência Sociais, 71, 5-19.

Richards, G. (2010). Putting Psychology in its place: Critical historical perspectives (3 ${ }^{\text {rd }}$ ed.). East Sussex: Routledge.

Richmond, O. (2014). Peace During and After the Age of Intervention. In L.Goetschel \& S. Pfluger (Eds.), Challenges of Peace Research (Working Paper n. 7 / 2014) (pp. 16-23). Bern: Swiss Peace.

Sanson, A., \& O'Connor, M. (2012). A Research Agenda for the Future: New Challenges for Peace Psychology in Australia. In D. Bretherton \& N. Balvin (Eds.), Peace Psychology in Australia (pp. 319-339). Australia: Springer.

Santos, B. S. (2002). Toward a multicultural conception of Human Rights. In B. HernándezTruyol, Moral Imperialism: A critical anthology (pp. 39-60). New York: New York University Press. 
Santos, B. S. (2013). Human Rights: A fragile hegemony. In F. Crépeau \& C. Sheppard (Eds.), Human Rights and Diverse Societies: Challenges and possibilities (pp. 17-26). Cambridge: Cambridge Scholars Publishing.

Santos, B. S. (2011). Se Deus fosse um Ativista dos Direitos Humanos. Coimbra: Almedina.

Santos, B. S. (2009). A Non-Occidentalist West? Learned Ignorance and Ecology of Knowledges. Theory, Culture \& Society, 26(7-8), 103-125. Dor: 10.1177/0263276409 348079

Santos, B. S. (2007). Beyond Abyssal Thinking: from Global Lines to Ecologies of Knowledge, Review, XXX(1), 45-89.

Sapio, A., \& Zamperini, A. (2007). Peace Psychology: Theory and Practice. In C. Webel \& J. Galtung (Eds.), Handbook of Peace and Conflict Studies (pp. 265-278). London: Taylor and Francis, LTD.

Tapia, S. (2011). El doble papel de los derechos humanos. Conocimiento y Cultura Jurídica, 5, 185-202.

Thiessen, T. (2011). Emancipatory Peacebuilding. Critical Responses to (Neo)Liberal Trends. In T. Matyók, J. Senehi \& S. Byrne (Eds.), Critical Issues in Peace and Conflict Studies. Theory, Practice, and Pedagogy (pp. 115-140). United Kingdom: Lexington Books.

Wagner, R. (1985). Psychology and the threat of nuclear war. American Psychologist, 40(5), 531-535. DOI: 10.1037/0003-066X.40.5.531

Wagner, R. (2001). Direct Violence. In D. Christie, R. Wagner \& D. Winter (Eds.), Peace, Conflict, and Violence: Peace Psychology for the 21st Century (pp. 15-17). New Jersey: Prentice-Hall.

Wessells, M. (1996). A History of Division 48 (Peace Psychology). In D. Dewsbury (Ed.), Unification Through Division: Histories of the Divisions of the American Psychology Association (pp. 233-264). Washington DC: American Psychological Association. 
Wessells, M., McKay, S., \& Roe, M. (2010). Pioneers in Peace Psychology: Reflections on the Series. Peace and Conflict, 16(4), 331-339. Dor: 10.1080/10781919.2010.518559

Wright, Q., Evan, W. M., \& Deutsch, M. (1962). Preventing World War III: Some Proposals. New York, NY: Simon and Schuster.

White, R. K. (1986). Psychology and the prevention of nuclear war. New York: New York University Press. 